\section{IJ§ER}

ISSN: $2149-5939$

International Journal of Social Sciences and Education Research

Online, http://dergipark.gov.tr/ijsser

Volume: 5(1), 2019

\title{
Homoeconomicus: the ultimate representative of rational economic behavior
}

\author{
Gelengül Koçaslan ${ }^{1}$
}

Received Date: $10 / 10 / 2018$

Accepted Date: 12 / $01 / 2019$

\begin{abstract}
Homoeconomicus is the top actor of economics. Economic theoretical insights, models, approaches and frameworks are built upon homoeconomicus also known as economic human. In order to act consistent with the theory and not to violate its basic tenets; homoeconomicus is equipped with some spesific characteristic properties. Homoeconomicus is designed as an unemotional, selfish, rational utility maximizer and was born as a perfect representative of the theory. Economic decision making and behavior is framed and interpreted according to this theoretical concept. In other words there is a dual structure both supports each other. Economic decisions and economic behavior under risk are discussed around a series of the axioms of the theory of expected utility which was suggested by John Von Neumann and Oscar Morgenstern in 1944. However there is a huge research provides evidence that the concept of homoeconomicus remains unsufficient to explain real life economic behavior. Economic behavior contradicts with the axioms of the theory of expected utility. This research examines the concept of homoeconomicus from a wider perspective considering axiomatic roots and rationality-irrationality, Allais Paradox, subjective expected utility, bounded rationality, prospect theory, value, gain, loss, altruistic punishment, fairness, trust and reciprocity. The aim of this research is to better understand homoeconomicus and why and how homoeconomicus fails in real economic life.
\end{abstract}

Keywords:Homoeconomicus, rationality, irrationality, expected utility theory, axioms

\section{Introduction}

In economics; economic behavior, economic decision making, decision making under risk and uncertainty are explained by the theory of expected utility which was suggested by John Von Neumann who is a mathematician and Oscar Morgenstern who is an economist in 1944 (Von Neumann ve Morgenstern, 1944). The theory of expected utility uses invariance, completeness (complete-ordering), transitivity, continuity, independence, unequal-probability, Archimedean, monotonicity, substitution (independence of irrelevant alternatives) axioms to explain economic preferences, decisions, choices and behavior. The axioms of the theory of expected utility are used to explain rational economic behavior; including rational economic decision making, rational economic choice and rational economic preferences. The theory of expected utility evaluates the concepts of rationality and irrationality in accordance with the axioms. As long as a behavior is consistent with the axioms of the theory it is called as "rational" and if it violates them it is called "irrational".

Although the theory of expected utility theory had gained great currency because of its solid axiomatic structure when it was suggested in 1944, inevitably it didn't take so long that the theory itself and its axioms were called into question. Theoretical view has been questioned since

${ }^{1}$ Assoc. Prof. Dr. , Istanbul University, Faculty of Economics, Department of Economics, TURKEY, kocaslan@istanbul.edu.tr 
Koçaslan, G. (2019). Homoeconomicus: the ultimate representative of rational economic behavior.International Journal of Social Sciences and Education Research, 5(1), 63-68.

1950s by several behavioral and experimental research to draw attention to the lack of the theory to explain real life economic behavior. Correspondingly the concept of homoeconomicus has been criticized as being quite fictional. Lately neuroeconomic research has provided evidence that economic behavior in real life doesn't accompany the theoretical insights. Alternative theories have been suggested to develop canonical economic theories so far.

This research calls into question the validity of the concept of homoeconomicus. The rest of the paper is organized as follows. Section one is the introduction part. In the section 2 axiomatic roots are explained within the context of the first counterexamples. Section 3 reveals homoeconomicus and alternative concepts suggested. Section 4 concludes.

\section{Questioning axiomatic roots}

Economic theoretical insights, models, approaches and frameworks are built upon homoeconomicus also known as economic human. In order to act consistent with the theory and not to violate its basic tenets; homoeconomicus is equipped with some specific characteristic properties. In a sense it is a dual structure both supports each other. Homoeconomicus is harmonised with the axioms of the theory of expected utility and is introduced as a rational, unemotional, selfish utility maximizer. Homoeconomicus has been the top actor of economics and was born as a perfect representative of the theory and rationality.

Several researches have investigated the concept of rationality within the context of the theory of expected utility (McFadden, 1999, Mongin, 1998, Weirich, 1986, Machina, 1981, Shoemaker, 1982, Machina 1982). The concept of rationality in economic analysis is a package where the other principle concepts such as invisible-hand and self-regulating economy are included. Consisting of several different packages that support each other and by means of very well written scenario the theory operates like clockwork consequently.

While opposing self-regulating economy Keynes were opening rationality concept up for discussion (Bastien and Cardoso, 2007:119, Keynes, 1936). In 1953 French Economist Maurice Allais revealed that economic behavior systematically violates the independence axiom of the theory which is also known as the heart and also the key axiom of the theory of expected utility. According to the independence axiom of the theory of expected utility when decisions are being made common components are ignored. For example, when a consumer is asked to make a choice between two consumption bundles $\mathrm{A}$ and $\mathrm{B}$ and if he/she prefers $\mathrm{A}$; independence axiom states that if another consumption bundle $\mathrm{C}$ is added to the consumption bundles $\mathrm{A}$ and $\mathrm{B}$, the consumer still prefers A to B independent of the common consumption bundle $\mathrm{C}$. His finding is known as "Allais Paradox". Violation of the independence axiom is known as "the common consequence effect" or "the common consequence problem".

In 1961 Daniel Ellsberg revealed similar violations of the axioms of the theory of expected utility. In 1954 Leonard Savage suggested subjective expected utility. In 1957 Herbert Simon revealed "bounded rationality" based on psychological reasoning indicating a finite mind.

In their famous paper "Prospect Theory: An Analysis of Decision Under Risk" Daniel Kahneman and Amos Tversky presented "prospect theory" as an alternative and a critique of the theory of expected utility in 1979. Kahneman and Tversky suggested a value function where value assigned to gains and losses. The value function is also steeper in the loss domain demonstrating sensitivity towards losses. Prospect theory provides evidence that losses are evaluated 
Koçaslan, G. (2019). Homoeconomicus: the ultimate representative of rational economic behavior.International Journal of Social Sciences and Education Research, 5(1), 63-68.

more compared to same amount of gains different from the theory of expected utility that pays attention to the final asset position. According to the prospect theory suggested by Kahneman and Tversky an asset position is perceived differently depending on the reference point.

\section{Questioning homoeconomicus}

In spite of its excellent mathematical structure the theory fails to explain economic behavior in everyday life. It fails to serve for economic problems in everyday life and correspondingly it fails to produce effective, sustainable policies and thus becomes distanced from tangible contributions to economic troubles at individual, national and international base. Homoeconomicus serves for the mentioned perfectly working mechanism and hence behaves, decides, prefers, chooses consistent with the theoretical insights. In this perfectly working mechanism homoeconomicus reaches every information he/she needs, withal correctly, whenever needed. For this reason, homoeconomicus knows which option to choose, where to invest, which item to buy in order to maximize utility. In such a system there is no way to fail. Although homoeconomicus succeeds in the theoretical world, fails in real life.

Findings of experimental games provide evidence that individuals exhibit altruistic behavior violating one of the basic tenets attributed to homoeconomicus: selfishness. The results of the ultimatum games showed that individuals display altruistic punishment leads to leave the game empty-handed just to punish the partner which is the violation of not only the basic principle of the theory of expected utility but also the basic postulate of economics; "more is better than less". There is a huge research reports that fairness, trust and reciprocity are the common motivations when making a decision (Güth et. al. , 1982, Forsythe et. al. , 1994, Boton and Zwick, 1995, Roth, 1995, Berg et. al. , 1995, Fehr et. al. , 1997, Fehr and Schmidt, 2003, Falk et. al., 2003, Cox, 2004, Kritikos ve Bolle, 2005, Chaudhuri and Gangadharan, 2005, Koçaslan, 2010, Mussel et. al. , 2013, Staffiero et. al. , 2013, Charness and Shmidov, 2014, Achtziger et. al. ,2016, Debove et.al. , 2016, Paz et. al. , 2017).

The violations of the axioms attributed to homoeconomicus' rational economic behavior are revealed and it is shown that economic behavior contradicts with the basic tenets of the theory (Allais, 1953, Simon, 1955, Tversky 1975, Kahneman and Tversky 1979, Tversky and Kahneman 1980, Tversky and Kahneman 1983a, Tversky and Kahneman 1983b, Roth et.al. , 1991, Tversky and Kahneman 1992, Tversky and Shafir 1992, Fehr and Gachter, 2000, Henrich et. al. , 2001, Camerer et. al, 2003, Agarwall and Vercelli, 2005, Kritikos and Bolle, 2005). In their research of homoeconomicus where theoretical assignments to homoeconomicus are called into question once more; Henrich et al. performed behavioral experiments in 15 small-scale societies and stated that canonical model is not supported in any society studied and fails in a wider variety of ways (Henrich et. al. , 2001).

When the concept of homoeconomicus has fallen to explain real life economic behavior; different concepts like homocorporativus adopting cooperative and associative economic behavior and other alternative models such as homoreciprocus, homodialogicus, homopoliticus, homopsychologicus, homoheuristicus, homoduplex, satisfier and heuristic decision-maker have been presented (Simon, 1955, Sahlins, 1972, Sen, 1977, Kahneman et. al. , 1982, Nyborg, 2000, Jager et. al. , 2000, Fehr and Fischbacher, 2003, Bastienand Cardoso, 2007, Kluver et. al. , 2014, Yamagishi et. al. ,2014:1699, Kent and Taylor, 2016). 
Koçaslan, G. (2019). Homoeconomicus: the ultimate representative of rational economic behavior.International Journal of Social Sciences and Education Research, 5(1), 63-68.

\section{Conclusion}

Homoeconomicus has been the ultimate representative of economics and economic rationality. Homoeconomicus' behavior, decisions, preferences and choices satisfy the axioms of the theory. So theoretical predictions support the concept of homoeconomicus and vice versa. As long as the research is made within the boundaries of the theory, all of the assumptions are valid and correct. However, it is expected from all branches of sciences to determine points of failures of the theories. Then it is possible to engage theories to real life.

Future predictions are made in order to develop future policies. In other words policies take form regarding to the predictions. In this case if predictions are wrong or insufficient, policies move away from objectives. When theories are engaged to real life properly then predictions made in order to develop future policies will serve real life and the solutions of economic problems in rel life accurately.

It is obvious that economic behavior in daily life conflicts with homoeconomicus concept and attributions are violated systematically. Violating the axioms of the theory of expected utility deserves to be analyzed carefully since it has noteworthy effects on the economy via the responses of individuals to economic policy. As a social science it is not possible to consider economics without human. This brings the need of usage of psychology, physiology, neuroscience, neurology, biology and genetics in economics. Current technological developments in the mentioned fields provide evidence to obtain measurements of emotions such as satisfaction, pleasure, pain and regret. The next step is to reshape "as if" approach and reconsider "ceteris paribus". Then the concept of homoeconomicus will be re-evaluated to serve for solving real life economic problems rather than merely meeting mathematical axioms and economics will move with the times as all branches of science should do.

\section{References}

Achtziger, A. , Alós-Ferrer, C. , \& Wagner, A. K. (2016). The impact of self-control depletion on social preferences in the ultimatum game.Journal of Economic Psychology, 53, 1-16.

Agarwall, B. , \& Vercelli, A.(2005). Introduction. In B. Agarwall, \&A. Vercelli (Eds.), Psychology, rationality and economic behavior:changing standard assumptions (pp. 1-15). New York, Palgrave Macmillan.

Allais, M. (1953). Le comportement de l'hommerationneldevantlerisque: critique des postulats et axiomes de l'ecoleAmericaine. Econometrica, 21 (4), 503-546.

Bastien, C. , \& Cardoso, J. L. (2007). From homo economicus to homo corporativus:A neglected critique of neoclassical economics. The Journal of Socio-Economics, 36, 118-127 .

Berg, J. , Dickhaut, J. , \& McCabe, K. (1995). Trust, reciprocity and social history. Games and Economic Behavior, 10, 122-42.

Camerer, C. F, Loewenstein, G. , \& Rabin R. (2003). (Eds.),Advances in behavioral economics. USA, Princeton University Press.

Charness, G. , \& Shmidov, V. (2014). Trust and Reciprocity. Foundations and Trendsin Microeconomics, 10(3), 167-207.

Chaudhuri, A. , \& Gangadharan, L. (2005). An experimental analysis of trust and trust-worthiness. Southern Economic Journal, 73(4), 959-985.

Cox, J. C. (2004). How to identify trust and reciprocity. Games and Economic Behavior, 46, 260-281. 
Koçaslan, G. (2019). Homoeconomicus: the ultimate representative of rational economic behavior.International Journal of Social Sciences and Education Research, 5(1), 63-68.

Debove, S. , Baumard, N. , \& André, J. B. (2016). Models of the evolution of fairness in the ultimatum game: a review and classification. Evolution and Human Behavior, 37, 245-254.

Falk, A. , Fehr, E. , \& Fischbacher, U. (2003). On the nature of fair behaviour. Economic Inquiry, 41(1), 20-26.

Fehr, E. , \& Schmidt, K. M. (2003). Theories of fairness and reciprocity - evidence and economic applications. In M. Dewatripont, L. P. Hansen \& S. J. Turnovsky (Eds.), Advances in Economics and Econometrics, Econometric Society Monographs, Volume 1,(pp. 208 - 257). Eighth World Congress.

Fehr, E. , \& Ga“chter, S. (2000). Fairness and retaliation: the economics of reciprocity. Journal of Economic Perspectives, 14(3), 159-81.

Fehr, E., Gächter, S. , \& Kirchsteiger, G. (1997). Reciprocity as a contract enforcement device. Econometrica, 65, 866-90.

Fehr, E. , \& Fischbacher, U. (2003). The nature of human altruism. Nature, 425, 785-791.

Forsythe, R. , Horowitz, J. L., Savin, N. E. \& Sefton, M. (1994). Fairness in simple bargaining experiments. Games and Economic Behavior, 6(3), 347-369.

Güth, W. , Schmittberger, R. , \& Schwarze, B. (1982). An experimental analysis of ultimatum bargaining. Journal of Economic Behavior and Organization, 3: 367-388.

Henrich J. , Boyd, R. , Bowles, S. , Camerer, C. , Fehr, E. , Gintis, H. , \& Mcelreath, R. (2001). In search of homo economicus: behavioral experiments in 15 small-scale societies. Economics And Social Behavıor, 91(2), 73-78.

Jager, W. , Janssen, M. A. , De Vries, H. J. M. , De Greef, J. , \& Vlek, C. A. J. (2000) Behaviour in commons dilemmas: homoeconomicusand homopsychologicusin an ecological-economic model. Special Issue The Human Actor In Ecological-Economic Models Ecological Economics, 35, 357-379.

Kahneman, D. , \& Tversky, A. (1979). Prospect theory:an analysis of decision under risk. Econometrica, 47(2), 263-291.

Kahneman, D. , Slovic, P. , \& Tversky, A. (1982). Judgment under uncertainty: Heuristics and biases. New York, Cambridge University Press.

Kent, M. L. , \& Taylor, M. (2016). Review from homoeconomicus to homodialogicus: rethinking socialmedia use in CSR communication. Public Relations Review, 42, 60-67.

Keynes, J.M. (1936). The general theory of employment, interest and money. London, Macmillan.

Kluver, J. , Frazier, R. , \& Haidt, J. (2014). Behavioral ethics for homoeconomicus, homoheuristicus, and homoduplex. Organizational Behavior and Human Decision Processes. 123, 150-158.

Koçaslan, G. (2010). Neuroeconomics: Bringing Neuroscience and Economics Together. Gaziantep Üniversitesi Sosyal Bilimler Dergisi, 9(3), 505-512.

Kritikos, A. , \& Bolle, F. (2005). Utility-based altruism:evidence from experiments. In B. Agarwall \& A. Vercelli (Eds.), Psychology, rationality and economic behavior:changing standard assumptions(pp. 181-194). New York, Palgrave Macmillan.

Machina, M. (1981). "Rational" decision making versus "rational" decision modelling. Journal of Mathematical Psychology, 24, 163-175.

Machina, M. (1982). "Expected utility" analysis without the independence axiom. Econometrica, 50, 277323.

McFadden, D. (1999).Rationality for economists. Journal of Risk And Uncertainty, 19(1), 73-105.

Mongin, P. (1998). Expected utility theory. In J. B. Davis, D. W. Hands, \& U. Mäki (Eds.), The handbook of economic methodology (pp.171-178). UK, Edward Elgar Publishing.

Mussel, P. , Hewig, J. , \& Göritz, A. S. (2013). Which choice is the rational one? An investigation of need for cognition in the ultimatum game. Journal of Research in Personality, 47, 588-591. 
Koçaslan, G. (2019). Homoeconomicus: the ultimate representative of rational economic behavior.International Journal of Social Sciences and Education Research, 5(1), 63-68.

Nyborg, K. (2000). Homo Economicus and Homo Politicus: interpretation and aggregation of environmental values. Journal of Economic Behavior \& Organization, 42, 305-322.

Paz, V., Nicolaisen-Sobesky, E. , Collado, E. , Horta, S. , Rey, C. , Rivero, M ., Berriolo, P . , Díaz, M. , Otón, M ., Pérez, A. , Fernández-Theoduloz, G. , Cabana, A. , \& Gradin, V. B. (2017). Effect of self-esteem on social interactions during the Ultimatum Game. Psychiatry Research, 252, 247-255.

Roth, A. (1995). Bargaining Experiments. In Kagel, J. H. , \& Roth, A. (Eds.), Handbook of Experimental Economics (pp. 253-342). USA, Princeton Univeristy Press.

Roth, A. E. , Prasnikar, V. , Okuno-Fujiwara, M. \& Zamir, S. (1991). Bargaining and market behavior in Jerusalem, Ljubljana, Pittsburgh, and Tokyo: an experimental study. American Economic Review, 81(5), 1068-95.

Sahlins, M. (1972). Stone age economics. London, Routledge.

Schoemaker, P. J. H. (1982). The expected utility model: Its variants, purposes, evidence and limitations. Journal of Economic Literature, 20( 2), 529-563.

Sen, A. K. (1977). Rational fools: A critique of the behavioral foundations of economic theory. Philosophy \& PublicAffairs, 6, 317-344.

Simon, H. (1955). A behavioral model of rational choice. Quarterly Journal of Economics, 69, 99-118.

Staffiero, G. , Exadaktylos, F. , \& Espín, A. M. (2013). Accepting zero in the ultimatum game does not reflect selfish preferences. Economics Letters, 121, 236-238.

Tversky, A. , \& Kahneman, D. (1992). Advances in prospect theory: cumulative representation of uncertainty. Journal of Risk and Uncertainty, 5:297-323.

Tversky, A. , \& Kahneman, D. (1980). Judgements of and by representativeness. In D. Kahneman, P. Slovic, A. Tversky (Eds.)Judgements Under Uncertainty: Heuristics and Biases(pp. 84-98). UK, Cambridge University Press.

Tversky, A. , \& Kahneman, D. (1983a). Judgment under uncertainty: heuristics and biases. Science, 185:1124-1131.

Tversky, A. , \& Shafir, E. (1992). The disjunction effect in choice under uncertainty. Psychol Sci. , 3:305-309.

Tversky, A. (1975). A critique of expected utility theory: descriptive and normative considerations. Erkenntnis, 9: 163-173.

Tversky, A. , \& Kahneman, D. (1983b). Extensional versus intuitive reasoning: the conjunction fallacy in probability judgement. Psychol Rev. , 90:293-315.

Von Neumann, J. , \& Morgenstern, O. (1944). Theory of games and economic behavior. USA, Princeton University Press.

Weirich, P. (1986). Expected utility and risk. The British Journal for the Philosophy of Science, 37(4), 419- 442.

Yamagishi, T. , Li, Y. , Takagishi, H. , Matsumoto, Y. , \& Kiyonari, T. (2014). In search of homoeconomicus. Psychological Science, 25(9), 1699-1711. 